\title{
A Prospective Study to predict Vaginal Cytology and Bishop Score as Predictors of Onset of Labor
}

\author{
1Jasneet Dhingra, ${ }^{2}$ Shashi Prateek, ${ }^{3}$ Poonam Mani
}

\section{COVER LETTER:}

Vaginal cytology reflects changes in estrogen and progesterone in pregnancy. The change represents a transition from predominance of navicular cells and clusters of intermediate cells (evidence of progesterone) to appearance of fewer or small sheets of clusters with abundance of superficial cells (evidence of progesterone withdrawal) at the onset of labor. Thus, vaginal cytology is a simple and inexpensive parameter to predict the onset of labor with ease. The vaginal smear yields unsurpassed speed and convenience.

Bishop score, a clinical parameter also predicts the onset of labor. At the onset of labor, Bishop score improves.

\section{ABSTRACT}

Aim: To study the changes in vaginal cytology and Bishop score in term pregnancy; to evaluate vaginal cytology and Bishop score as predictors of onset of labor and to compare individual and combined efficacy of both parameters.

Materials and methods: The study was conducted in Department of Obstetrics and Gynecology in Subharti Medical College, Meerut.

All antenatal patients, who were at term or at risk of preterm delivery [such as those presenting with preterm premature rupture of membranes (PPROM) or with warning signs for preterm labor], were enrolled as the study subject. Patients who were already in established labor or subjected to elective cesarean section were excluded from the study.

Each subject was explained about the nature of study and informed written consent was taken. Per speculum examination was done. Leaking, if present, was noted and confirmed with $\mathrm{pH}$ change and fern test. Smear were taken from upper one-third of vaginal wall prior and smeared on a glass slide and was fixed in alcohol and stained according to Papanicolaou method. In each smear, individual cell characteristics as well as degree of desquamation was noted.

The condition of cervix was evaluated by means of Bishop score. The Bishop score thus estimated was recorded in the working proforma.

The patient's vaginal smear for cytology and repeat Bishop score was taken every 24 hours, till the onset of labor. Date and time of onset of labor was noted.

\footnotetext{
${ }^{1}$ Senior Resident, ${ }^{2}$ Professor and Head, ${ }^{3}$ Associate Professor

${ }^{1-3}$ Department of Obstetrics and Gynecology, Netaji Subhash Chandra Bose Subharti Medical College, Meerut, Uttar Pradesh India

Corresponding Author: Shashi Prateek, Professor and Head Department of Obstetrics and Gynecology, Netaji Subhash Chandra Bose Subharti Medical College, Meerut, Uttar Pradesh, India, Phone: +919313700855, e-mail: shashiprateek@ yahoo.com
}

Results: The maximum number of subjects were seen in the age category 18 to 24 . Most of the women were primi gravida and were between 38 and 39 gestational age group. The decrease in number of clusters at the onset of labor was found statistically significant. Bishop score is increased at the onset of labor as compared to prelabor.

Conclusion: Vaginal cytology is a simple and inexpensive parameter to predict the onset of labor with ease. The vaginal smear yields unsurpassed speed and convenience.

Bishop score, a clinical parameter, also predicts the onset of labor. At the onset of labor, Bishop score improves.

Keywords: Bishop score, Pregnancy, Vaginal cytology.

How to cite this article: Dhingra J, Prateek S, Mani P. A Prospective Study to predict Vaginal Cytology and Bishop Score as Predictors of Onset of Labor. J South Asian Feder Obst Gynae 2016;8(3):222-230.

Source of support: Nil

Conflict of interest: None

Date of received: 7 May 2016

Date of acceptance: 13 June 2016

Date of publication: July 2016

\section{INTRODUCTION}

Labor refers to the onset of effective uterine contractions leading to progressive effacement and dilation of cervix, resulting in expulsion of fetus, placenta, and membranes.

It rests on the statistical fact that the average duration of pregnancy in women is 40 weeks or 280 days. In about $60 \%$ of cases, patients delivered within a week in either direction and in $80 \%$ cases between 38 and 41 weeks. The date of onset of labor cannot be predicted with accuracy by any specific method. Attempts to define the exact time of onset of labor have led to much discussions and controversies.

The uterine activity gradually increases and becomes more coordinated during last weeks of pregnancy. Prelabor changes that start a few weeks before the actual commencement of labor are significant to predict the onset of labor.

While the exact cause and the mechanism for the onset of labor ${ }^{1}$ are not known, the principle factors in the initiation of labor according to different theories are:

- Hormonal factor

- Fetal placental factor 
- Mechanical factor

- Prostaglandins.

It is a combination of abovementioned factors that results in onset of labor. The whole process is gradual, slowly developing in late pregnancy rather than sudden onset of activity. The cervix gets ready to allow passage of products of conception and simultaneously myometrium gets prepared to begin effective uterine contraction to expel the same.

The prediction of onset of labor plays an important role in deciding management protocol for patients with premature rupture of membrane and other conditions requiring termination of pregnancy, particularly with preterm patients. To solve this problem, parameters, such as vaginal cytology, serum progesterone and estradiol levels, relaxin, fetal fibronectin, IGFBP-1, and cytokines in cervical secretions have been studied.

Presently, various theories that predict the onset of labor include:

- C19 steroids which are transported in the fetal blood to placenta $^{2}$

- Progesterone withdrawal (McDonald and Nathanielsy 1991) $)^{3}$

- Rise in levels of estrogen in pregnancy

- Prostaglandins ${ }^{4,5}$

- $\mathrm{CRH}^{6}$

- Interaction of brain pituitary adrenal glands ${ }^{7}$

- Relaxin

An effort to describe how the onset of labor starts, brings together number of changes taking place in fetus, placenta, placental membrane, decidua, myometrium, and cervix. ${ }^{8}$ With respect to estrogen and its metabolites evidence has been accumulated that estriol excretion continues to rise from the 7 th week of gestation through delivery ${ }^{8,9}$ and does not change the day before, on the day of, or during delivery. ${ }^{10-13}$

Analyses of progesterone and its metabolites reveal that plasma pregnandiol gradually rises throughout gestation and does not drop until after delivery. ${ }^{14-16}$

The cytokines, such as interleukin (IL)-1, IL-6, IL-8, and fetal fibronectin ${ }^{18,19}$ are involved in cervical ripening and initiation of labor. Produced in choriodecidual space, fetal fibronectin leaks into cervix and vagina, becomes detectable in usually 1 to 2 weeks before the onset of labor. Insulin-like growth factor binding protein 1 (IGFBP-1 $)^{20,21}$ is a protein synthesized by maternal decidua. Its concentration increases during pregnancy in maternal circulation.

Conditions of cervix (cervical ripening) can be predicted by Bishop score. Cervical ripening is influenced by prostaglandin E-2. ${ }^{22}$ The markers and tests utilized are expensive and do not reliably predict labor many times.
The increasing levels of hormones after conception bring about changes in vaginal epithelium. They can be detected by examination of vaginal smears which reveals intermediate cell clusters and navicular cells. This cytological pattern changes suddenly at the end of pregnancy due to drop in hormonal levels. This pattern brings about spontaneous labor within 5 days. ${ }^{23-25}$

Endocrine interpretation of vaginal smear becomes first line of attack for the clinicians, as it is inexpensive and fast. Using cytologic methods, a change in end organ has been postulated by a large number of authors. ${ }^{26,27}$

Vaginal cytology is a simple and inexpensive parameter. During pregnancy, vaginal cytology reflects changes in estrogen and progesterone. Changes due to these hormones are proliferation of vaginal epithelium, particularly intermediate layer, desquamation of large number of squamous cells. The finding, increased number of cells from superficial layer, is suggestive of diminished estrogen activity few days prior to labor.

The term "navicular cell of pregnancy" was coined by Papanicolaou. ${ }^{28}$ In 1933 the term "navicular cell" was used and it was felt to be diagnostic for presence of a pregnancy. ${ }^{29}$

The 3rd trimester smear is composed of numerous clusters of navicular cells and these are mature folded intermediate cells. ${ }^{30-32}$

The onset of labor can also be predicted by condition of cervix by Bishop score.

Bishop score, also Bishop's score, also known as Cervix score is a prelabor scoring system to assist in predicting whether induction of labor will be required. ${ }^{33}$ It has also been used to assess the odds of spontaneous preterm delivery. $^{34}$

In the 1960s, Edward Bishop, MD, developed a fivecomponent point-based scoring system to determine the possibility of an uncomplicated pregnancy at term with a successful vaginal delivery. The Bishop score does not relate to the length of the labor, or the ease or difficulty of the labor and delivery of the baby. It only relates to the potential success or failure of a vaginal delivery outcome.

\section{Parameters of Bishop Score}

\begin{tabular}{llllll}
\hline Score & $\begin{array}{l}\text { Dilatation } \\
\text { of cervix }\end{array}$ & $\begin{array}{l}\text { Effacement } \\
\text { of cervix }\end{array}$ & $\begin{array}{l}\text { Fetal } \\
\text { station }\end{array}$ & $\begin{array}{l}\text { Position } \\
\text { of cervix }\end{array}$ & $\begin{array}{l}\text { Consistency } \\
\text { of cervix }\end{array}$ \\
\hline 0 & Closed & $30 \%$ & -3 & $\begin{array}{l}\text { Posterior } \\
\text { Firm }\end{array}$ & Firm \\
1 & $1-2 \mathrm{~cm}$ & $40-50 \%$ & -2 & $\begin{array}{l}\text { Moderately } \\
\text { position }\end{array}$ & firm \\
2 & $3-4 \mathrm{~cm}$ & $60-70 \%$ & -1 & Anterior & Soft \\
3 & $>5 \mathrm{~cm}$ & $80 \%$ & +1 & & \\
\hline
\end{tabular}

The Bishop score has a clinical significance in determining the course of labor. If the Bishop score is $<5$, the patient is 
unlikely to start labor without an induction (i.e., chemical, cervical ripening assistance, or cesarean consideration). If the Bishop score is 8 or higher, the patient is more likely to begin labor spontaneously. ${ }^{35}$

\section{MODIFIED BISHOP SCORE}

According to the Modified Bishop preinduction cervical scoring system, effacement has been replaced by cervical length in centimeter, as shown below ${ }^{36}$ :

\section{Parameter of Modified Bishop Score}

\begin{tabular}{llllll}
\hline Score & $\begin{array}{l}\text { Dilatation } \\
\text { of cervix }\end{array}$ & $\begin{array}{l}\text { Effacement } \\
\text { of cervix }\end{array}$ & $\begin{array}{l}\text { Fetal } \\
\text { station }\end{array}$ & $\begin{array}{l}\text { Position } \\
\text { of cervix }\end{array}$ & $\begin{array}{l}\text { Consistency } \\
\text { of cervix }\end{array}$ \\
\hline 0 & Closed & $>3 \mathrm{~cm}$ & -3 & $\begin{array}{l}\text { Posterior } \\
\text { Mid- }\end{array}$ & Firm \\
1 & $1-2 \mathrm{~cm}$ & $>2 \mathrm{~cm}$ & -2 & $\begin{array}{l}\text { Moderately } \\
\text { position }\end{array}$ & firm \\
& & & & Anterior & Soft \\
2 & $3-4 \mathrm{~cm}$ & $>1 \mathrm{~cm}$ & -1 & & \\
3 & $>5 \mathrm{~cm}$ & $>0 \mathrm{~cm}$ & +1 & & \\
\hline
\end{tabular}

Surprisingly, the published discussion of the cytologic appearance of smears from pregnant women has been quite limited and references are not available for last many years. Nowadays biochemical markers like fetal fibronectin and IGFBP-1 are emphasized and extensively studied, though they are expensive and mostly of little value in low resource settings. Considerable emphasis has not been devoted to cytology in pregnancy, though it is economical and of great importance and can be easily used in low resource settings and serve the masses. Keeping this in mind, the present study was done to study vaginal cytology, and Bishop score as predictors of onset of labor.

\section{MATERIALS AND METHODS}

This study was conducted at the Department of Obstetrics and Gynecology in Subharti Medical College and associated Chatrapati Shivaji Hospital, Meerut, over a period of 2 years from September 2012 to July 2014.

\section{Study Design: Prospective Study}

All antenatal patients admitted to Department of Obstetrics and Gynecology in Subharti Medical College, who were term or at risk of preterm delivery [such as those presenting with preterm premature rupture of membranes (PPROM) or with warning signs for preterm labor], were enrolled as the study subject. Patients who were already in established labor or subjected to elective cesarean section were excluded from the study.

Each subject was explained about the nature of study in their own language and informed written consent was taken. The women's detailed history, including age, parity, obstetric history, medical history was documented and general physical and obstetrical examination was performed.
Her last menstrual period was noted and correlated with gestational age estimation according to mid-second trimester (16-20 weeks) scan wherever possible. Per speculum examination was done. Leaking, if present, was noted and confirmed with $\mathrm{pH}$ change and fern test. Smears were taken from upper one-third of vaginal wall prior to digital examination with a sterile wooden spatula and smeared on a glass slide and was fixed in alcohol for 20 minutes duration and stained according to Papanicolaou method.

Three stains used in Pap stain are:

1. Hematoxylin

2. OG-6 stain

3. EA-50.

OG-6 is a monochromatic stain and EA-50 is a polychromatic stain.

\section{Steps of Papanicolaou Method}

- Slide was immersed in 95\% ethanol for 15 minutes (fixation)

- Slide rinsed in tap water

- Immersed slide in Gill hematoxylin for 1 to 3 minutes

- Rinsed slide in tap water

- Slide dipped 10 times in 95\% ethanol

- Slide kept in OG-6 stain for 1.5 minutes

- Slide dipped 10 times in 95\% ethanol

- Slide immersed in EA-50 for 2.5 minutes

- Slide dipped 10 times in 95\% ethanol

- Immersed slide in $100 \%$ ethanol for 1 minute

- Slide cleared with xylene

- Slide mounted with permanent mounting medium.

Each smear was examined at magnification of $40 \times$ and individual cell characteristics as well as degree of desquamation were noted. The degree of desquamation was evaluated by estimating:

- Number of intermediate cells per cluster

- Number of superficial cells

- Size of cell clusters.

Condition of cervix was evaluated by means of Bishop score. The Bishop score thus estimated was recorded in the working proforma.

The patient's vaginal smear for cytology and repeat Bishop score was taken every 24 hours, till the onset of labor which was defined as occurrence of regular, painful uterine contractions resulting in progressive cervical effacement and dilatation. Date and time of onset of labor was noted.

\section{RESULTS}

\section{Age}

The maximum number of subjects are seen in the age category 18 to 24 and minimum number of subjects were seen in the category 25 to 31 . The mean age of all the subjects is 25.20 years with standard deviation of 3.58 . 


\section{Parity}

Most of the women were primi gravida (44.4\%). Thirteen percent participants were gravida four or more.

\section{Gestational Age}

Graph 1 denotes that most of the women were between 38 and 39 gestational age group $(68 \%)$.

\section{Comparison of Superficial Cells in Pap Smears (Prelabor and at Onset of Labor) $(n=142)$}

There is significant increase in the mean superficial cells in onset of labor group in comparison to prelabor group $(\mathrm{p}<0.001)$ (Table 1). The difference of superficial cells (prelabor and at onset of labor) is shown by bar diagram (Graph 2).

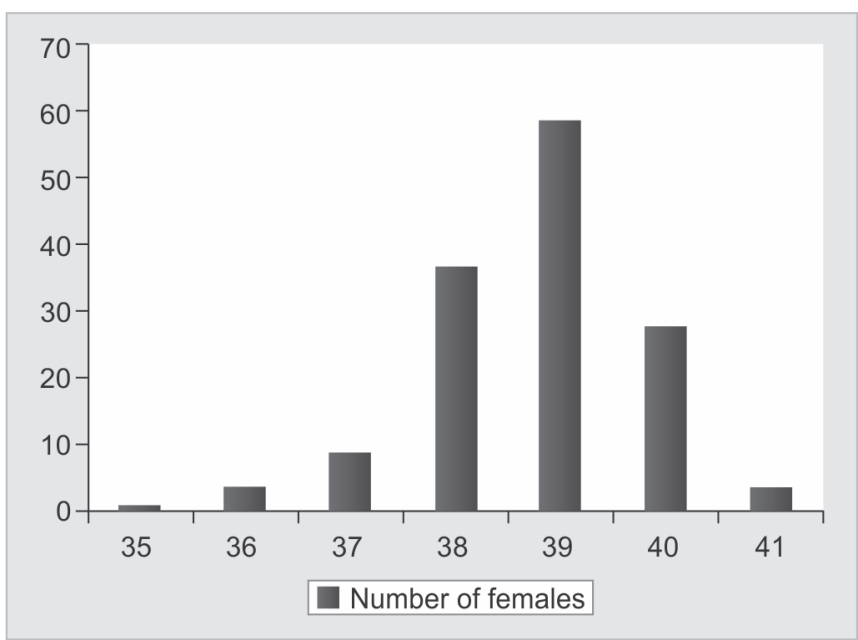

Graph 1: Gestational age distribution of subjects $(n=142)$

Table 1: Comparison of superficial cells in Pap smears

\begin{tabular}{lllr}
\hline No. of cells & Mean & $\begin{array}{l}\text { Standard } \\
\text { deviation }\end{array}$ & $p$-value \\
\hline Prelabor & 45.09 & 8.233 & $<0.001^{*}$ \\
At onset of labor & 54.37 & 5.157 & \\
\hline
\end{tabular}

*Significant if $p<0.05$

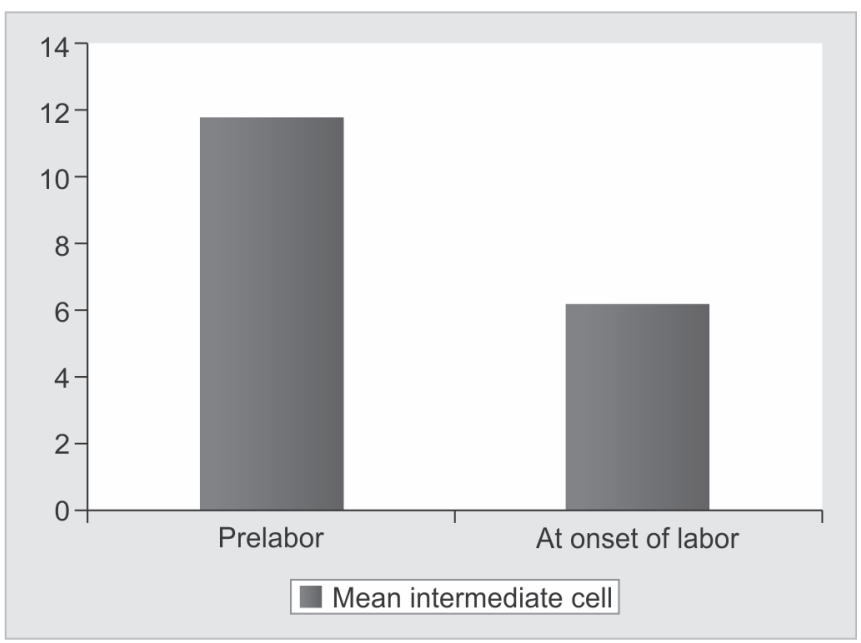

Graph 3: Mean intermediate cells (prelabor and at onset of labor)

\section{Comparison of Intermediate Cells in Pap Smear (Prelabor and at Onset of Labor) $(n=142)$}

The significant decrease in mean intermediate cell was observed in vaginal smear taken at onset of labor $(p<0.001)$ (Table 2). It is obvious from the bar diagram shown below that the height of bar is just half in case of intermediate cells at onset of labor in comparison to bar of pre labor (Graph 3).

\section{Comparison of Clusters in Pap Smears (Prelabor and at Onset of Labor) $(n=142)$}

The comparison of clusters from prelabor slides to onset of labor is shown in Table 3. The decrease in number of clusters at onset of labor was found statistically significant $(\mathrm{p}<0.001)$ and is also shown in Graph 4.

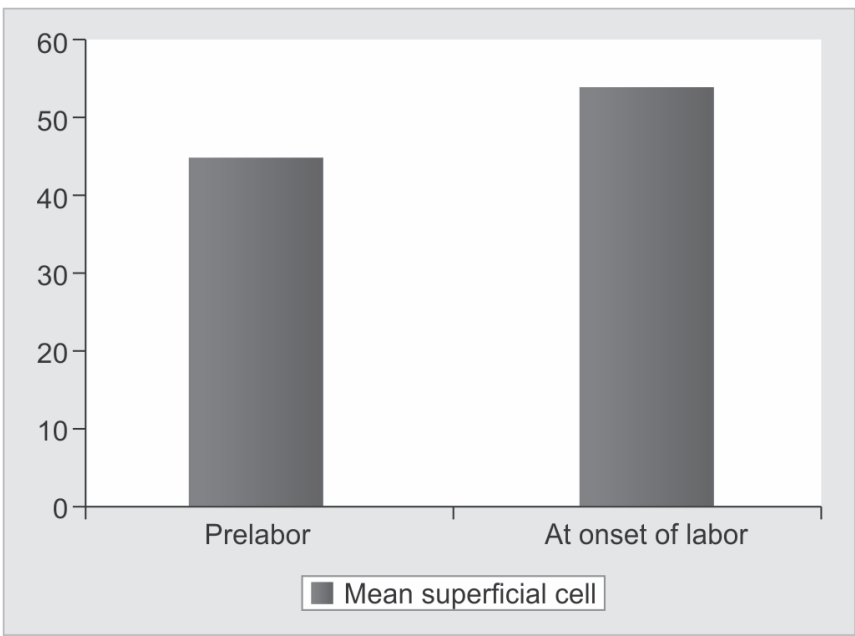

Graph 2: Mean superficial cells (pre labor and at onset of labor)

Table 2: Comparison of intermediate cells in Pap smear

\begin{tabular}{lllc}
\hline No. of cells & Mean & $\begin{array}{l}\text { Standard } \\
\text { deviation }\end{array}$ & $p$-value \\
\hline Prelabor & 11.78 & 2.824 & $<0.001^{*}$ \\
At onset of labor & 6.26 & 1.346 & \\
\hline
\end{tabular}

*Significant if $p<0.05$

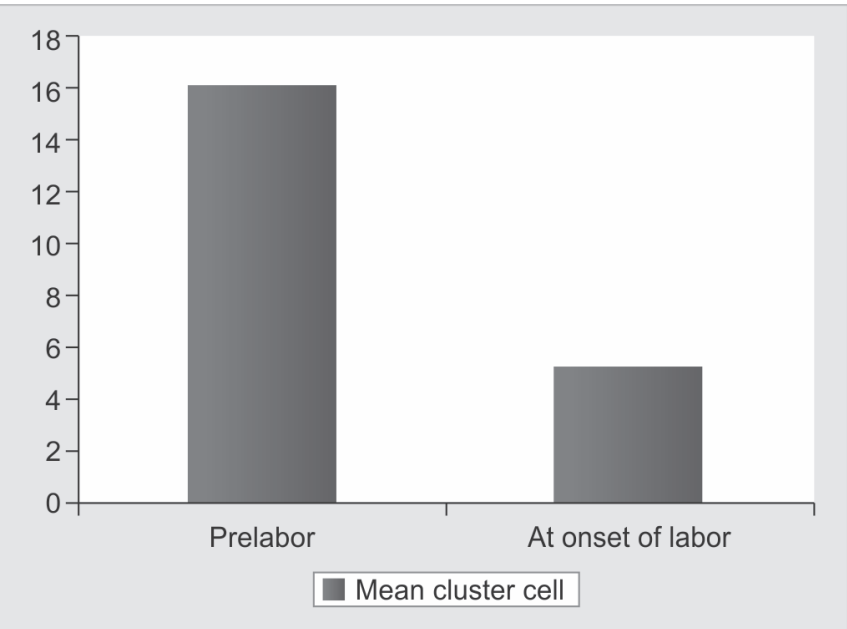

Graph 4: Mean clusters (prelabor and at onset of labor) 
Table 3: Comparison of clusters in Pap smears

\begin{tabular}{lllr}
\hline No. of clusters & Mean & $\begin{array}{l}\text { Standard } \\
\text { deviation }\end{array}$ & p-value \\
\hline Prelabor & 16.01 & 3.661 & $<0.001^{*}$ \\
At onset of labor & 5.23 & 1.319 & \\
\hline *Significant if $\mathrm{p}<0.05$ & & &
\end{tabular}

Table 4: Comparison of Bishop score

\begin{tabular}{llll}
\hline Bishop score & Mean & $\begin{array}{l}\text { Standard } \\
\text { deviation }\end{array}$ & p-value \\
\hline Prelabor & 3.66 & 0.47 & $<0.001^{*}$ \\
At onset of labor & 4.54 & 0.99 & \\
\hline
\end{tabular}

*Significant if $p<0.05$

\section{Comparison of Bishop Score during Labor, Prelabor, and at Onset of Labor $(n=142)$}

From Table 4, one can see that mean Bishop score is increased at onset on labor from prelabor, and this increase in mean Bishop score was found statistically significant.

\section{Onset to Delivery Time Interval $(n=142)$}

The number of days from onset to delivery time was also noted. Table 5 depicts that maximum number of subjects delivered in 1 to 2 days after onset of labor.

\section{Correlation of Onset of Labor to Delivery Time Interval to Different Type of Cells at Onset of Labor in Pap Smear $(n=142)$}

In this study different types of cell were studied at onset of labor and relation between these calls to onset to delivery time interval was observed. The correlation of delivery time to the different types of cell at onset is shown in Table 6. Further, it is noticed that delivery time is positively correlated with the number of intermediate cells $(p=0.02)$ and the number of clusters $(\mathrm{p}=0.018)$. The correlation of these values for onset to delivery time interval was found to be statistically significant. The correlation between

Table 5: Onset to delivery time interval

\begin{tabular}{ll}
\hline Number of subjects & $\begin{array}{l}\text { Onset to delivery time } \\
\text { interval (in days) }\end{array}$ \\
\hline 58 & 1 \\
49 & 2 \\
19 & 3 \\
15 & 4 \\
1 & 5 \\
\hline
\end{tabular}

Table 6: Correlation of onset of labor to delivery time interval to different type of cells

\begin{tabular}{lll}
\hline Type of cells & Delivery time & $p$-value \\
\hline Superficial cell & $r=-0.097$ & 0.25 \\
Intermediate cell & $r=0.195^{*}$ & 0.02 \\
Cluster cell & $r=0.198^{*}$ & 0.018 \\
\hline
\end{tabular}

${ }^{*}$ Correlation is significant at the 0.05 level (two-tailed) superficial cells and the onset to delivery time interval is inversely proportional $(\mathrm{p}=0.25)$.

\section{Correlation of Onset to Delivery Time Interval to Bishop Score at Onset of Labor $(n=142)$}

The correlation between onset to delivery time interval with the Bishop score was studied. Table 7 shows that onset to delivery time interval is strongly correlated with the Bishop score at onset of labor and it was found to be statistically significant ( $p=0.018)$. It is concluded that as Bishop score increases, there is a decrease in the onset to delivery time interval.

\section{Duration of Changes in Vaginal Cytology and Bishop Score from Prelabor to Onset of Labor}

Table 8 shows that the duration of changes in vaginal cytology and Bishop score from prelabor to onset of labor within 2 to 4 days.

\section{DISCUSSION}

The vaginal smear obtained in pregnancy reflects the hormonal function of the placenta and its production of estrogen and progesterone. Both the clinical signs of impending labor and Naegele's rule give only an approximate estimate of date of confinement and are of little practical value in predicting when labor will occur. Several authors have indicated that the vaginal cytology is an accurate method of estimating when a pregnancy is at term and can be used to predict the onset of labor.

In this study vaginal cytology and Bishop score were studied to predict the onset of labor.

This study included 142 antenatal patients and patient's vaginal smear for cytology and repeat Bishop score were taken every 24 hours, till the onset of labor. The average age of the subjects included in the study

Table 7: Correlation of onset to delivery time interval to Bishop score at onset of labor

\begin{tabular}{lcl}
\hline & Delivery time & $p$-value \\
\hline Bishop score & $\mathrm{r}=-0.742^{*}$ & 0.018 \\
\hline${ }^{*}$ Correlation is significant at the 0.01 level (two-tailed) &
\end{tabular}

Table 8: Duration of changes in vaginal cytology and Bishop score from prelabor to onset of labor

\begin{tabular}{lll}
\hline $\begin{array}{l}\text { Number of } \\
\text { participants (in } \\
\text { percentage) }\end{array}$ & $\begin{array}{l}\text { Duration of change } \\
\text { in vaginal cytology at } \\
\text { onset of labor (in days) }\end{array}$ & $\begin{array}{l}\text { Duration of change in } \\
\text { Bishop's score at onset }\end{array}$ \\
\hline 25 & 2 & 2 \\
50 & 3 & 3 \\
75 & 4 & 4 \\
\hline
\end{tabular}


was 25 years. Most of the women were primigravida and maximum were between 38 and 39 weeks gestational age $(68 \%)$.

The comparison of superficial cells from prelabor and at onset of labor was done. It was observed that number of superficial cells are increased at onset of labor. There was slight increase in superficial cells with progress of pregnancy because at onset of labor, there is progesterone hormone withdrawal. The cytologic pattern changes prior to labor due to drop in hormone progesterone levels and the change represents abundance of superficial cells at onset of labor.

The result was compared with other studies and discussed as follows:

This finding correlated with the study of Aikat (1973) and Hammond (1965) that superficial cells increase at onset of labor can predict onset of labor. Similarly, the present study result correlates with study of Hammond.

Initially, there is predominance of intermediate cells with massive evidence of progesterone effect. At onset of labor, predominant intermediate cells lose their navicular morphology and are shed as flat, individual cells or in small sheets. The present study was done to see this cytologic change at onset of labor in relation to intermediate cells.

It is also observed that there is decrease in intermediate cells in the vaginal smears from prelabor to onset of labor due to cytologic changes which occur due to change in hormone levels and this shows the cytologic pattern changes suddenly at the end of pregnancy. The average intermediate cells present at prelabor were 11 and at onset of labor 6. In a study done by Pandit and Kalgutkar, they observed large clumps of intermediate cells prelabor and single intermediate cells or occasional small clumps of intermediate cells at onset of labor. Similarly, Ghafoorzadeh et $\mathrm{al}^{38}$ recorded clumped smears in 38\% patients. In these studies, smears were taken few days prior to onset of labor and were observed. In the present study, smears were taken 24 hourly till onset of labor. Also, the difference of clusters in prelabor slides and at onset of labor slides was observed. It was found that there is decrease in number of clusters at onset of labor as compared to prelabor. The mean clusters at prelabor were 16 and 5 at onset of labor. In a study done at Royal Maternity Hospital, Belfast on 123 patients, the vaginal smears were clumped smears (cells arranged in clumps) in $38 \%$, partly discrete (reduction in number and size of clusters) in $32 \%$ patients, and discrete (almost or completely depleted of cell clumps) in $28 \%$ patients. Lichtfus recorded at term changes in $97.3 \%$ patients. Study was done in 369 patients. Also, study done at Postgraduate Institute of Medical Education and Research, Chandigarh, at the onset of labor smears showed tiny clumps or discrete cell only.

At term, with progesterone withdrawal there is appearance of relatively fewer sheets or clusters. Therefore, endocrine interpretation of vaginal smear can predict onset of labor and demonstrate change in cytologic smear obtained. The vaginal cytology is inexpensive, fast, and available on a repetitive basis.

Bishop score, a clinical parameter, was studied and its variability at prelabor and onset was also seen. Bishop score starts improving at onset of labor. A study done by Strobel et $\mathrm{al}^{42}$ showed Bishop score can be used for prediction of time at onset of labor. Laughon et $\mathrm{al}^{43}$ used simplified Bishop score to predict vaginal delivery. The value of cervical score in predicting successful onset of labor was studied.

The onset of labor to delivery time interval was also noted in this study in relation to superficial cells, intermediate cells, clusters, and Bishop score. As the superficial cells increases at onset of labor, number of superficial cells are inversely proportional to onset of labor to delivery time interval. Number of intermediate cells and clusters decreases at onset of labor; they are directly proportional to onset to delivery time interval. Bishop score is also strongly correlated with the onset of labor to delivery time interval. It is concluded that as the Bishop score increases, there is decrease in onset to delivery time interval.

The change in cytologic pattern brought spontaneous labor within 5 days. ${ }^{30,39,44}$ The average onset to delivery time interval in this study of 142 subjects was 2 to 3 days.

Birtch in 1961 studied hormonal cytology in pregnancy. He obtained, before term smears in 53\% patients, approaching term smears in $42 \%$ patients, and at term smears only in $5 \%$ of patients, out of 208 patients within 5 days of onset of labor. Lichtfus recorded "at term" changes in $97.3 \%$ and "prior to term" changes in $2.7 \%$ of patients within 5 days of spontaneous delivery in 369 patients.

Therefore, it is possible to predict the onset of labor by vaginal cytology when the smears show tiny clumps of intermediate cells. The vaginal cytology is a useful parameter for the prediction of onset of labor in pregnancy. Bishop score, a clinical parameter is also found to be useful in prediction of onset of labor (Tables 9 to 12)..

Table 9: Comparison of superficial cells at prelabor and onset of labor in different studies

\begin{tabular}{|c|c|c|c|c|}
\hline $\begin{array}{l}\text { SI. } \\
\text { no. }\end{array}$ & Study & Years & $\begin{array}{l}\text { Number of } \\
\text { superficial cells } \\
\text { (prelabor) }\end{array}$ & $\begin{array}{l}\text { Number of } \\
\text { superficial cells } \\
\text { (at onset of labor) }\end{array}$ \\
\hline 1 & Aikat $^{37}$ & 1973 & Decrease & Increase \\
\hline 2 & Hammond ${ }^{38}$ & 1965 & Decrease & Increase \\
\hline 3 & $\begin{array}{l}\text { Present } \\
\text { study }\end{array}$ & 2014 & Decrease & Increase \\
\hline
\end{tabular}


Table 10: Comparison of intermediate cells in clusters in different studies

\begin{tabular}{|c|c|c|c|}
\hline $\begin{array}{l}\text { SI. } \\
\text { no. }\end{array}$ & Years & Study & $\begin{array}{l}\text { No. of patients showing } \\
\text { smears with clusters of } \\
\text { intermediate cells }\end{array}$ \\
\hline 1 & 1986 & Pandit and Kalgutkar ${ }^{39}$ & 34 \\
\hline 2 & 1965 & Ghafoorzadeh et al ${ }^{38}$ & 38 \\
\hline 3 & 1973 & Aikat $^{37}$ & 40 \\
\hline 4 & 2014 & Present study & 142 \\
\hline
\end{tabular}

Table 12: Comparison of onset to delivery time interval in different studies

\begin{tabular}{|c|c|c|c|}
\hline $\begin{array}{l}\text { SI. } \\
\text { no. }\end{array}$ & Study & Years & $\begin{array}{l}\text { Onset to } \\
\text { delivery interval }\end{array}$ \\
\hline 1 & Lichtfus $^{30}$ & 1959 & 5 \\
\hline 2 & Birtch $^{44}$ & 1961 & 5 \\
\hline 3 & Pandit and Kalgutkar ${ }^{39}$ & 1986 & 5 \\
\hline
\end{tabular}

\section{CONCLUSION}

It was concluded that parameters vaginal cytology and Bishop score can be used for the prediction of onset of labor. Vaginal cytology reflects changes in estrogen and progesterone in pregnancy.

The change represents a transition from predominance of navicular cells and clusters of intermediate cells (evidence of progesterone) to appearance of fewer or small sheets of clusters with abundance of superficial cells (evidence of progesterone withdrawal) at onset of labor. Thus, vaginal cytology is a simple and inexpensive parameter to predict onset of labor with ease. The vaginal smear yields unsurpassed speed and convenience.

Bishop score, a clinical parameter, also predicts onset of labor. At the onset of labor, Bishop score improves.

\section{ACKNOWLEDGMENTS}

It is indeed a very pleasant opportunity to express this heartfelt note of thanks to all those persons without whose guidance, help, and participation, this thesis would not have seen the light of day.

It is a great privilege for me to carry out this study under the expert guidance of my Chief supervisor Prof. Shashi Prateek, Department of Obstetrics and Gynecology, NSCB Subharti Medial College, Swami Vivekanand Subharti University, Meerut. A fountainhead of knowledge, her guidance has proved invaluable in my work. Her pearls of wisdom coupled with valuable criticism have contributed largely in my way for completion of this work. Throughout my work, she provided me with the best of literature, making my journey into realism of knowledge and easier. Her emphasis on punctuality, perseverance, and being systematic has helped me in improving myself constantly.
Table 11: Comparison of clusters in different studies

\begin{tabular}{|c|c|c|c|}
\hline $\begin{array}{l}\text { SI. } \\
\text { no. }\end{array}$ & Years & Study & $\begin{array}{l}\text { Smears showing } \\
\text { decrease in number } \\
\text { of clusters }\end{array}$ \\
\hline 1 & 1964 & Osmond-Clarke et al ${ }^{40}$ & $58 \%$ \\
\hline 2 & 1966 & Willis and Harley ${ }^{41}$ & $28 \%$ \\
\hline 3 & 1959 & Lichtfus $^{30}$ & $97.3 \%$ \\
\hline
\end{tabular}

She supervised several dimensions of the present study with indispensable care and responsibility. Above all, she always provided me with unflinching encouragement and support in various ways. Her truly scientific attitude has made her as a constant oasis of ideas and passions in science, which exceptionally inspire and enrich my growth as a student and a researcher. In fact, she remained a constant source of encouragement throughout the period in the research work. I am indebted to her more than she knows.

I also avail this opportunity to thank Prof U.K. Ghosh, Head of Department of Obstetrics and Gynecology, for his valuable advices and help during the course of the study.

I endeavor to express my deep sense of gratitude to my co-supervisor Dr. Poonam Mani, Department of Obstetrics and Gynecology, NSCB Subharti Medical College, Meerut. Her guidance has proved invaluable in my work. Her valuable advice has contributed largely in my way toward completion of this work. It goes without saying that without her help, this work would have not taken the current shape.

I am also thankful to Dr. Parul Garg, Department of Obstetrics and Gynecology. It is difficult to put in words the constant support and her guidance which made my work easier.

My sincere thanks to Prof Anjali Khare, Department of Pathology, NSCB Subharti Medial College, Swami Vivekanand Subharti University, Meerut. Her disciplined approach to life and stress on punctuality and hard work will be remembered throughout my life.

Also thanks to Dr. Ganesh Singh, Department of Community Medicine, LLRM Medical College. His useful suggestions and analytical approach has helped me a lot in statistical calculations in completing this thesis.

I cannot put to words my gratitude for my parents and my brother who have been the guiding spirit in my life. It is their efforts, unconditional love, and affection that has helped me to reach this position. They have given me the opportunity of education from the best institutions and support throughout my life. Words fail to express what I owe them for their care and gentle love.

My special thanks are due to all the patients who consented to participate in this study. My thanks to all the subjects who cooperated most willingly in this study. 
My deepest feelings of gratitude are directed to all my teachers, seniors, and juniors for their skillful guidance and support in following up the patients throughout the study.

I would also like to convey thanks to the administrative staff of Subharti Medical College for cooperating and providing the excellent facilities and a pleasant working atmosphere to carry out this research.

I am also thankful to God!!! With His blessings I was able to complete my work.

\section{—Dr Jasneet Dhingra}

\section{REFERENCES}

1. Navitsky J, Greene JF, Curry SL. The onset of human labor. Prim Care Update Ob Gyns 2000 Sep;7(5):197-199.

2. Concannon PW, Powers ME, Holder W, Hansel W. Pregnancy and parturition in the bitch. Biol Reprod 1977 May;16(4): 517-526.

3. Siiteri PK, MacDonald PC. The utilization of circulating dehydroepiandrosterone sulfate for estrogen synthesis during human pregnancy. Steroids 1963;2:713-730.

4. Challis JRG, Matthews SG, Gibb W, Lye SJ. Endocrine and paracrine regulation of birth at term and preterm. Endocr Rev 2000 Oct;21(5):514-550.

5. Challis JRG. Characteristics of parturition. In: Creasy RK, Resnik R, editors. Maternal-fetal medicine. 4th ed. Philadelphia (PA): WB Saunders; 1999. p. 484.

6. Karalis K, Goodwin G, Majzoub JA. Cortisol blockade of progesterone: a possible molecular mechanism involved in the initiation of human labor. Nat Med 1996 May;2(5):556-560.

7. Frandsen VA, Stakemann G. The site of production of oestrogenic hormones in human pregnancy. Acta Endocrinol 1961 Nov;38:383-391.

8. Greene JW, Touchstone JC, Fields H. Urinary estriol as an index of placental function. Obstet Gynecol 1961 Mar;17:349-354.

9. Taylor ES, Bruns PD, Duncan IW, Drose VE. Urinary estriol determinations in normal pregnancy. Am J Obstet Gynecol 1961 Apr;81:625-629.

10. Frandsen VA, Stakemann G. Urinary excretion of estriol during normal pregnancy. Dan Med Bull 1960 Jul;7:95-98.

11. Napp JH, Tonguc M, Karaaliler S. Estrogen and pregnanediol excretion before, during and after delivery. Arch Gynak 1960;194:1-12.

12. Venning EH. Endocrine changes in normal pregnancy. Am J Med 1955 Nov;19(5):721-723.

13. Zondek B, Pfeifer V. Further studies on urinary estriol excretion during pregnancy and its significance for estimation of placental function and dysfunction in advanced pregnancy. Acta Obstet Gynecol Scand 1959 Jan;38(4):742-761.

14. Deshpande GN, Sommerville IF. Plasma pregnandiol in human pregnancy. Lancet 1958 Nov 15;2(7055):1046-1049.

15. Deshpande GN, Turner AK, Sommerville IF. Plasma pregnandiol in human pregnancy, during labor and postpartum. J Obstet Gynaecol Br Emp 1960 Dec;67:954-961.

16. Short RV. Blood progestrone levels in relation to parturition. J Reprod Fertil 1960 Feb;1:61-70.

17. Shynlova O, Lee YH, Srikhajon K, Lye SJ. Physiologic uterine inflammation and labor onset: integration of endocrine and mechanical signals. Reprod Sci 2013 Feb;20(2):154-167.
18. Lockwood CJ, Senyei AE, Dische MR, Casal D, Shah KD, Thung SN, Jones L, Deligdisch L, Garite TJ. Fetal fibronectin in cervical and vaginal secretions. N Engl J Med 1991 Sep 5;325(10):669-674.

19. Iams JD, Casal D, McGregor JA, Goodwin TM, Kreaden US, Lowensohn R, Lockitch G. Fetal fibronectin improves the accuracy of diagnosis of preterm labor. Am J Obstet Gynecol 1995 Jul;173(1):141-145.

20. Audibert F, Fortin S, Delvin E, Djemli A, Brunet S, Dubé J, Fraser WD. Contingent use of fetal fibronectin testing and cervical length measurement in women with preterm labour. J Obstet Gynaecol Can 2010 Apr;32(4):307-312.

21. Committee on Practice Bulletins-Obstetrics, The American College of Obstetricians and Gynecologists. Practice bulletin no. 130: prediction and prevention of preterm birth. Obstet Gynecol 2012 Oct;120(4):964-973.

22. Calder AA, Dension F. Inflammatory mediators in cervix. 2004.

23. Malek J, Mobil-Kova J, Cech E, Kozel D. Vaginal cytology patterns during biologic preparation for labour. Acta Cytol 1967 Nov-Dec;11(6):444-448.

24. Pundel JP. Vaginal cytology at the end of pregnancy. Acta Cytol 1959;3:253-263.

25. Ruiz LM. Vaginal cytology during delivery. Acta Cytol 1965 Sep-Oct;9(5):337-339.

26. Hartemann J, Ribon M, Heymans M. Relation between the aspect of vaginal smear and the course of labor. Bull Fed Soc Gynaecol Obstet 1962;14:435-437.

27. Leeton JF. The use of vaginal cytology in late pregnancy. J Obstet Gynaecol Br Commonw 1963;70:46-49.

28. Papanicolaou GN. The diagnosis of early human pregnancy by the vaginal smear method. Proc Soc Exp Biol Med 1925;22:436.

29. Papanicolaou GN. The sexual cycle in the human female as revealed by vaginal smears. Am J Anat 1933;52(Suppl): 519-637.

30. Lichtfus CP. Vaginal cytology at end of pregnancy. Acta Cytol 1959;3:247.

31. Neiburgs HE. Normal vaginal cytology during pregnancy. Acta Cytol 1959;3:211.

32. Pundel JP. The practical value of vaginal smear at the end of pregnancy. Transactions of the Seventh Annual Meeting of Inter-Society Cytology Council; 1959. p. 9-18.

33. Bishop EH. Pelvic scoring for elective induction. Obstet Gynecol 1964 Aug;24:266-268.

34. Newman RB, Goldenberg RL, Iams JD, Meis PJ, Mercer BM, Moawad AH, Thom E, Miodovnik M, Caritis SN, Dombrowski M, et al. Preterm prediction study: comparison of the cervical score and bishop score for prediction of spontaneous preterm delivery. Obstet Gynecol 2008 Sep;112(3):508-515.

35. Tenore JL. Methods for cervical ripening and induction of labor. Am Fam Physician 2003 May 15;67(10):2123-2128.

36. Dutta DC. Text book of obstetrics. 6th ed. New Central Book Agency; 2001.

37. Aikat $\mathrm{M}$. The practical value of vaginal cytology in the third trimester of normal pregnancy. Indian J Pathol Bacteriol 1973;16:5-9.

38. Hammond DO. A critical evaluation of the value of vaginal cytology for the determination of biologic term. Acta Cytol 1965 Sep-Oct;9(5):340-343.

39. Pandit A, Kalgutkar AK. The value of vaginal cytology in prediction of labour with special reference to eosinophilic and karyopyknotic indices. J Postgrad Med 1986 Oct;32(4):210-213. 
40. Osmond-Clarke F, Murray M, Wood C. Endocrine cytology in pregnancy-cytological changes before normal and premature labor. J Obstet Gynaecol Br Commonw 1964 Apr;71:231-236.

41. Willis J, Harley JMG. Value of the vaginal smear in the investigation of amenorrhea. Br Med J 1966 Feb 12;1(5484):399-401.

42. Strobel E, Sladkevicius P, Rovas L, De Smet F, Karlsson ED, Valentin L. Bishop score and ultrasound assessment of the cervix for prediction of time to onset of labor and time to delivery in prolonged pregnancy. Ultrasound Obstet Gynaecol 2006 Sep;28(3):298-305.

43. Laughon SK, Troendle J, Sun L. Bishop score to predict vaginal delivery. Obstet Gynaecol 2011 Apr;117(4):805-811.

44. Birtch PK. Hormonal cytology in pregnancy. Clin Obstet Gynecol 1961;4:1062.

45. Abrams RY, Abrams J. Vaginal cytology during the final week of pregnancy. Acta Cytol 1962 Jul-Aug;6:359-364.

46. Barnes AC, Zuspan FP. Vaginal cytology as an index of the date of confinement. J Obstet Gynaecol (Am) 1956 May;71(5): 1080-1088.
47. Chopra R, Verma K, Buckshee K. Role of vaginal cytology in prediction of onset of labour. Indian J Med Res 1978 Aug;68:279-284.

48. Engineer AD, Tandon L, Ramchandran S. Vaginal cytology in late pregnancy and at term. J Obstet Gynaecol 1967;17: 491-496.

49. Soule SD. The practical value of vaginal cytology in pregnancy. Acta Cytol 1964 Sep-Oct;8:368-372.

50. Claire WM, Esfahani FM. Pregnancy-related changes: a retrospective review of 278 cervical smears. Diagn Cytopathol 1996;17(2):99-106.

51. Larsen B, Markovetz AJ, Galask RP. The bacterial flora of female rat genital tract. Proc Soc Exp Biol Med 1976 Mar;151(3): 556-562.

52. Tadao KK, Okamoto H. J Clin Pathol (Am) 2000;114(Suppl 1): S6-S20.

53. Mark CW, Krammer J, O'Brien WF. Bishop score to predict vaginal delivery. Obstet Gynaecol 1997 Nov;90(5):784-789. 